\title{
JOUVE, Vincent. Por que estudar literatura? Tradução de Marcos Bagno e Marcos Marcio- lino. São Paulo: Parábola editorial, 2012.
}

\author{
Rita Jover-Faleiros ${ }^{1}$
}

$\mathrm{O}$ que se ensina quando se ensina literatura? $\mathrm{O}$ que ler? $\mathrm{O}$ que pode a literatura hoje diante da disseminação em ritmo cada vez mais vertiginoso dos recursos audiovisuais da web? O texto literário reserva alguma singularidade a ponto de exigir reflexão metodológica quando da sua constituição como objeto didático? Os bestsellers são literatura e suas adaptações para o cinema uma porta de acesso à formação do gosto pela leitura junto ao público infanto-juvenil?

A propósito do binômio literatura e escola não são poucas as questões que se colocam para o público composto por professores e pesquisadores. Seja, por um lado, por estes se verem diante de relativo esgotamento dos modelos de ensino vigentes (cuja abordagem ainda parece bastante pautada pelo ensino de uma história literária); seja, por outro, por se verem diante dos jovens leitores mobilizados por narrativas de bruxos voadores, vampiros apaixonados e lobisomens obcecados, o que implica a dificuldade dos professores para: a) selecionar outras obras literárias a serem lidas e estudadas em contexto escolar e; b) trazer essas obras literárias de maneira a também interessar esses jovens leitores.

Ambas as questões (a seleção de obras e o modo de trabalhá-las) parecem passar pela própria justificativa da constituição do objeto, ou seja, a literatura como algo passível de ser ensinado e aprendido: mas enfim por que estudar literatura? Se pensarmos no procedimento borgeano descrito por Umberto Eco ${ }^{2}$ (1992) segundo o qual um leitor é artifício desenvolvido pelos livros para que estes possam conversar entre si, poderíamos estabelecer um diálogo entre textos publicados por Perrone-Moisés, no Brasil, e Jouve, na França. Para a autora:

curiosamente, enquanto a literatura perdia seu prestígio no ensino [...] ela se adaptou aos novos tempos. A edição e a circulação de obras literárias

DOI: $10.1590 / 0104-4060.36289$

1 Universidade Federal de São Paulo. Escola de Filosofia, Letras e Ciências Humanas. Guarulhos, São Paulo, Brasil. Av. Monteiro Lobato, 679. CEP 07112-000.

2 ECO, Umberto. De superman au surhomme. Paris: Grasset, 1992. p. 172. 
ganhou um grande impulso com a informatização [...] os escritores premiados saíram de seus gabinetes para se tornar "celebridades" midiáticas [...] E tudo isso continua ocorrendo como se o conceito de literatura não tivesse sofrido nenhum abalo teórico, como se todos soubessem tacitamente o que é literatura. ${ }^{3}$

Com efeito, nos últimos dez anos, assistimos à publicação de uma série de obras cuja temática converge para o questionamento desse binômio, abordado de diferentes formas. Assim, títulos sugestivos apontam para isso, como $A$ literatura em perigo, de Tzvetan Todorov (São Paulo: Difel, 2009), Literatura para quê? de Antoine Compagnon (Belo Horizonte: Editora da UFMG, 2009) e Como falar dos livros que não lemos? de Pierre Bayard (Rio de Janeiro: Objetiva, 2009), todos publicados na França e, no Brasil, não podemos deixar de mencionar o também sugestivo título de Joel Rufino dos Santos para seus "ensaios indisciplinados": Quem ama literatura não estuda literatura (Rio de Janeiro: Rocco, 2008).

Vincent Jouve parece sensível a essa percepção das implicações de um saber tacitamente compartilhado sobre o tema e responde, enfrentando a questão que intitula sua obra, por meio da delimitação do objeto. Nela trata de responder à espinhosa tarefa de circunscrever o domínio do literário, pois, para o autor, se há uma crise dos estudos literários que implicaria suspeitas sobre a pertinência de se ensinar literatura, nas altas instâncias institucionais, que decidem sobre o financiamento das políticas culturais, editoriais e dos currículos escolares, entretanto, as escolhas continuam a ser feitas apesar dessa crise e, no outro extremo desse circuito - em uma de suas terminalidades -, a sala de aula, local especular das políticas culturais, editoriais e curriculares, o professor deve poder dispor de repertório para responder a essa pergunta - por que estudar literatura? Jouve, pois, afirma:

se a arte não existe mais para os teóricos, ela ainda existe para a maioria dos indivíduos e, sobretudo, para uma série de instituições (ensino, imprensa, mídias) que pesam fortemente sobre nossa existência cotidiana. Assim, talvez não seja inútil se interrogar sobre uma "realidade" que, mesmo mal definida, "informa" - através de uma série de engrenagens - o mundo em que vivemos e nossa existência no interior desse mundo (JOUVE, 2012, p. 10-11).

3 PERRONE-MOISÉS, L. O ensino da literatura. In: NITRINI, S. Literatura, artes e saberes. São Paulo: Abralic/Hucitec, 2008. p. 15. 
O enriquecimento da existência, o desenvolvimento do espírito crítico ao reforçar as capacidades de análise e reflexão do leitor, implicando uma liberdade de juízo e ampliação da experiência humana que a literatura veicula são as razões que justificam para Jouve o estudo da literatura. Assim, para responder à pergunta, mobiliza discussões teóricas a propósito da arte em suas dimensões estética, histórica e cultural por meio das duas grandes perguntas que organizam a primeira parte da obra: "a arte existe?", "a literatura existe?", promovendo "interlúdios" à guisa de ilustração do debate por meio da análise de trechos de textos literários, recurso eminentemente pedagógico que já aponta, ao delimitar o objeto, para o modo como explorá-lo em contexto didático.

Na tradução, Marcos Bagno e Marcos Marciolino optaram por naturalizar alguns exemplos de obras ou eventos históricos, aproximando alguns debates ao público brasileiro, mas mantiveram as obras analisadas que compõem os interlúdios.

Trata-se, sem dúvida, de obra de referência para a área de metodologia do ensino da literatura; sobretudo pelo esforço empreendido pelo autor de coligir os debates teóricos nos estudos literários como forma de responder a uma pergunta - por que estudar literatura? - que não está na origem desses debates e franqueando, dessa forma, um acesso a eles para um público em fase de formação inicial. Neste caso, vale destacar também que se Jouve se lança à empreitada de síntese teórica como forma de divulgação - assim como fizera em A leitura (São Paulo: Editora da Unesp) em 2002; seu olhar está voltado para o passado, principalmente nas propostas de leitura que oferece, todas pertencentes a um cânone literário francês (Nerval, Flaubert, Graac, entre outros). Ainda que reitere a necessidade de perguntar à obra literária - na tradição dos trabalhos de Robert Jauss - quais diferentes respostas ela oferece ao público leitor ao longo da história de sua recepção, Jouve permanece fiel à perspectiva do texto literário que promove uma ruptura formal com sua época, como forma de inovação no campo, paradigma de leitura atrelado a uma tradição teórica e crítica que merece ser ressignificada, sobretudo para aqueles que refletem sobre o ensino da literatura.

Texto recebido em 26 de abril de 2014. Texto aprovado em 03 de maio de 2014. 
